\title{
Houses, pots and food: the pottery from Maharski prekop in context
}

\author{
Dimitrij Mlekuž, Andreja Žibrat Gašparič, Milena Horvat and Mihael Budja \\ Department of Archaeology, Faculty of Arts, University of Ljubljana, SI \\ dmlekuz@gmail.com; andreja.zibrat.gasparic@gmail.com; Milena.Horvat@ff.uni-lj.si; miha.budja@ff.uni-lj.si
}

\begin{abstract}
In this paper, we attempt a multiscalar analysis of the Maharski prekop archaeological site, connecting the landscape context, temporal dynamics, and spatial organisation with the composition of the artefact assemblage, the shapes, sizes and technological composition of the pottery, and traces of activities in the form of food residues on pottery. The pottery assemblage from Maharski prekop is characterised by a wide variation in vessels. This can be explained by the non-specialised use of vessels, where they were deliberately designed to be able to perform a series of different functions, which is supported by the technological analysis of fabrics and the wide range of identified foodstuffs, interesting contexts with an abundance of anthropomorphic figurines are presented and discussed.
\end{abstract}

IZVLEČEK - V članku predstavljamo rezultate večnivojske analize najdišča Maharski prekop na Ljubljanskem barju. Pokrajinske kontekste, časovno dinamiko najdišča in njegovo prostorsko organizacijo smo povezali s podatki o sestavi artefaktnega zbira, oblikami, velikostjo in tehnološkimi značinostmi keramike ter s podatki o sledovih aktivnosti, dokazane z ohranjenimi sledovi hrane $v /$ na lončenini. Za keramični zbir z Maharskega prekopa je značilna velika variabilnost posod. To si lahko razlagamo kot nespecializirano uporabo lončenine, kjer so bile posode namenoma oblikovane za celo serijo različnih funkcij, kar so podprle tako tehnološke analize lončarskih mas kot širok razpon prepoznanih vrst živil.

KEY WORDS - pottery; pile dwellings; Ljubljansko Barje; Eneolithic

\section{Introduction}

The Ižica floodplain is the micro-region on Ljubljansko Barje that has been most intensively investigated in the past 137 years. Three main archaeological research and fieldwork episodes can be recognised during this period. The first relates to Dragotin Dežman's 'pile dwellings' discovery and the excavation of several large areas of approximately $12000 \mathrm{~m}^{2}$. Unfortunately, only scant fieldwork documentation was provided (Korošec P., Korošec J. 1969). The second episode comprises Resnikov prekop (Korošec 1964; Bregant 1964), Maharski prekop (Bregant 1974a; 1974b; 1975) and Parte (Harej 1978; 1981; 1987) excavations. The interdisciplinary approach and sophisticated recording procedures and techniques that were introduced for the Maharski prekop site excavation are worth noting. Systematic palynological (Šercelj 1975; 1981-1982; Šercelj, Culiberg 1978) and soil analyses (Stritar 1975; Stritar, Lobnik 1985) run parallel. They have all resulted in detailed site archives that include palaeoenvironmental data and conventional radiocarbon dates, along with catalogues of pottery and other artefact assemblages. The third episode comprises intensive fieldwork (Velušcek 2006) on the landscape and settlement dynamics in the micro-region (Budja 1994/ 1995; 1997; Mlekuž, Budja and Ogrinc 2006). Remote sensing research has enabled new insights into landscape taphonomy and revealed a pattern of palaeochannels that structured the landscape and affected the Maharski prekop site. Radiocarbon dating 
was applied to show the correlation between settlement and landscape dynamics (Budja, Mlekuž 2008; 2010).

The scale of analysis often determines the range of questions raised about data and the narratives we produce (Jones 2002). Microscale studies, studies of pottery technology, its chemical composition and studies of organic traces preserved in pottery are nested in a wider context of human daily practices and activities. Decontextualized analyses are in danger of being abstracted from their archaeological context and cannot contribute to the wider discussion and narratives.

This paper is an attempt at a multiscalar analysis of the Maharski prekop archaeological site, approaching it in terms of landscape context, temporal dynamics, spatial organisation, the composition of its artefact assemblage, the shapes, sizes and technological composition of the pottery to the traces of activities as indicated on pottery in the form of food residues. The purpose is to integrate a wide range of data into a holistic, multiscalar picture of the site. Detailed and more technical aspects of analyses of organic residues on pottery are presented in a complementary paper (Ogrinc et al. this volume). A more plausible alliance between microscale analytical procedures and interpretative archaeology is possible only by nesting the results of microscale analyses within wider narratives.

\section{Maharski prekop}

The excavations of the Maharski prekop site from 1970 to 1977 by Tatjana Bregant are the largest excavation of a settlement in the Ljubljansko Barje area so far, since a large area of around $1220 \mathrm{~m}^{2}$ was excavated (Bregant 1974a; 1974b; 1975; with unpublished documentation from excavations in 1976 and 1977). However, test trenches excavated in the vicinity of the site, pile clusters in the Ižica River and in the ditch at Maharski prekop, cores and sediment exposures from the immediate environs of the site suggest that the settlement extended even further across the floodplain.

A lidar image reveals that the Maharski prekop site is set in a landscape criss-crossed by a network of palaeochannels (Fig. 1). The organic infill of the palaeochannel that runs parallel to the site dates the silting up of the channel to 2833-2466 calBC, attesting that the channel was abandoned before that date. Part of this palaeochannel was already excavated during Bregant's campaigns, where a row of piles located at the edge of the channel was interpreted as a revetment that protected the site from bank erosion. Maharski prekop was located next to an active channel. The lidar survey thus revealed a complex microtopography, which makes this area suitable for settlement, and suggests a very dynamic landscape of seasonal floods and shifting palaeochannels (Mlekuž, Budja and Ogrinc 2006; Budja, Mlekuž 2010).

\section{Sequence of radiocarbon dates}

The Maharski prekop sequence is comprised of 35 radiocarbon dates (Tab. 1; Fig. 2). Besides the series of 6 conventional dates on wooden piles completed in the 1970s and 5 AMS radiocarbon dates obtained from animal bones, an additional 22 AMS radiocarbon dates of carbonised food residues on pottery were obtained recently. The wooden structures of Maharski prekop are dated between 4226 and 2631 calBC, but the dates of bones yielded a much narrower span between 3641 and 3372 calBC, with only one outlier, which was dated to 5615 and 5475 calBC (Mlekuž, Budja and Ogrinc 2006.Tab. 1).

A new series of direct dates of pottery significantly contributes to the chronology of the site (Fig. 3). The sum of distribution of AMS radiocarbon dates demonstrates roughly a bimodal distribution of probabilities, with a period of intensive occupation dating between 4400 and $4000 \mathrm{calBC}$, and a second occupa-

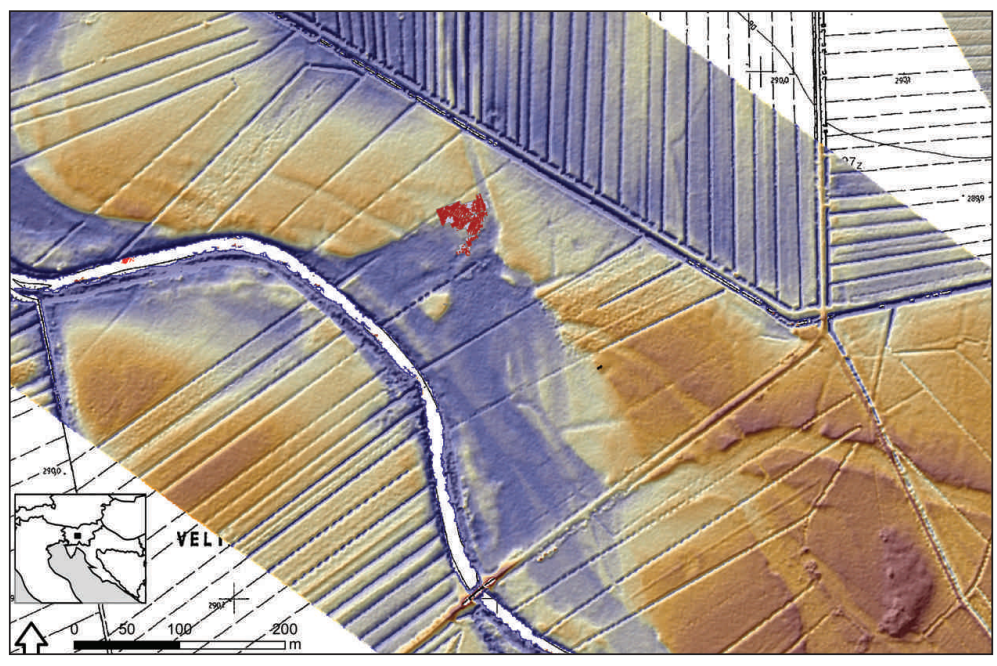

Fig. 1. Maharski prekop in a landscape context. 


\begin{tabular}{|c|c|c|c|c|c|c|c|c|}
\hline $\begin{array}{l}\text { Sample } \\
\text { n. }\end{array}$ & $\mid \begin{array}{c}\text { Conse- } \\
\text { cutive } n .\end{array}$ & Site & Context & Material & Lab code & $\begin{array}{c}\text { Conventional } \\
\text { BP }\end{array}$ & CalBC & Median \\
\hline \multirow[t]{5}{*}{ 15LJ } & $\mathrm{MP}_{226}$ & Maharski prekop & $\begin{array}{l}\text { excavations } 1977 \text {, } \\
\text { grid sq. } 60\end{array}$ & $\begin{array}{l}\text { food residue } \\
\text { on potery }\end{array}$ & Poz-48519 & $3920 \pm 35$ & $2547-2291$ & 2406 \\
\hline & & Maharski prekop & $\begin{array}{l}\text { excavations } 1974, \\
\text { test trench } 4\end{array}$ & wood & Z-353 & $4330 \pm 120$ & $3354-2631$ & 2991 \\
\hline & & Maharski prekop & $\begin{array}{l}\text { excavations } 1973 \text {, } \\
\text { grid sq. } 15, \text { pile } 1\end{array}$ & $\begin{array}{l}\text { wood } \\
\text { (Fraxinus) }\end{array}$ & Z-305 & $4345 \pm 113$ & $3357-2671$ & 3011 \\
\hline & & Maharski prekop & $\begin{array}{l}\text { excavations } 1974, \\
\text { grid sq. } 12 \text { ?, pile } 40\end{array}$ & $\begin{array}{l}\text { wood } \\
\text { (Quercus?) }\end{array}$ & Z-278 & $4633 \pm 117$ & $3646-3026$ & 3392 \\
\hline & & Maharski prekop & $\begin{array}{l}\text { sediment exposure } \\
\mathrm{MP}_{1} \text {, layer } 61-63 \mathrm{~cm}\end{array}$ & charcoal & $\mathrm{AA}-27182$ & $4680 \pm 55$ & $3632-3362$ & 3463 \\
\hline \multirow[t]{6}{*}{$\overline{14 \mathrm{LJ}}$} & $\mathrm{MP}_{177}$ & Maharski prekop & $\begin{array}{l}\text { excavations } 1977, \\
\text { grid sq. } 62\end{array}$ & $\begin{array}{l}\text { food residue } \\
\text { on potery }\end{array}$ & Poz-48518 & $4700 \pm 40$ & $3630-3369$ & 3464 \\
\hline & & Maharski prekop & $\begin{array}{l}\text { excavations } 1974, \\
\text { grid sq. } 15 \text {, pile } 4\end{array}$ & $\begin{array}{l}\text { wood } \\
\text { (Sorbus) }\end{array}$ & Z-315 & $4701 \pm 104$ & $3698-3106$ & 3477 \\
\hline & & Maharski prekop & grid sq. 42 & bone & Beta-219608 & $4710 \pm 40$ & $3633-3372$ & 3495 \\
\hline & & Maharski prekop & grid sq. 42 & bone (Ovis) & Beta-219607 & $4720 \pm 40$ & $3635-3374$ & 3511 \\
\hline & & Maharski prekop & grid sq. 42 & bone (Ovis) & Beta-219606 & $4740 \pm 40$ & $3638-3377$ & 3543 \\
\hline & & Maharski prekop & grid sq. 32 & bone & Beta-219611 & $4740 \pm 40$ & $3638-3377$ & 3543 \\
\hline \multirow[t]{2}{*}{ 19LJ } & $\mathrm{MP} 2$ & Maharski prekop & $\begin{array}{l}\text { excavations 1970, } \\
\text { grid sq. 1-8 }\end{array}$ & $\begin{array}{l}\text { food residue } \\
\text { on potery }\end{array}$ & Poz-48659 & $4750 \pm 35$ & $3636-3379$ & 3563 \\
\hline & & Maharski prekop & grid sq. 34 & bone & Beta-219610 & $4750 \pm 50$ & $3641-3376$ & 3547 \\
\hline$\overline{21 L J}$ & $\mathrm{MP}_{223}$ & Maharski prekop & $\begin{array}{l}\text { excavations 1974, } \\
\text { grid sq. } 32\end{array}$ & $\begin{array}{l}\text { food residue } \\
\text { on potery }\end{array}$ & Poz-48661 & $4755 \pm 35$ & $3637-3379$ & 3566 \\
\hline$\overline{16 L J}$ & MP227 & Maharski prekop & $\begin{array}{l}\text { excavations } 1977, \\
\text { grid sq. } 64\end{array}$ & $\begin{array}{l}\text { food residue } \\
\text { on potery }\end{array}$ & Poz -48520 & $4760 \pm 40$ & $3638-3378$ & 5363 \\
\hline$\overline{17 \mathrm{LJ}}$ & $\mathrm{MP} 123$ & Maharski prekop & $\begin{array}{l}\text { excavations 1970, } \\
\text { grid sq. } 2\end{array}$ & $\begin{array}{l}\text { food residue } \\
\text { on potery }\end{array}$ & Poz-48521 & $4790 \pm 35$ & $3648-3385$ & 3568 \\
\hline$\overline{05 \mathrm{LJ}}$ & MP171 & Maharski prekop & $\begin{array}{l}\text { excavations 1977, } \\
\text { grid sq. } 47\end{array}$ & $\begin{array}{l}\text { food residue } \\
\text { on potery }\end{array}$ & Poz-48507 & $4810 \pm 35$ & $3654-3519$ & 3570 \\
\hline$\overline{\mathrm{O}} \mathrm{LI}$ & $\mathrm{MP}_{158}$ & Maharski prekop & $\begin{array}{l}\text { excavations } 1977 \text {, } \\
\text { grid sq. } 47\end{array}$ & $\begin{array}{l}\text { food residue } \\
\text { on potery }\end{array}$ & Poz-48506 & $4860 \pm 40$ & $3710-3527$ & 3653 \\
\hline $11 \mathrm{LJ}$ & MP17 & Maharski prekop & $\begin{array}{l}\text { excavations 1972, } \\
\text { grid sq. } 14\end{array}$ & $\begin{array}{l}\text { food residue } \\
\text { on potery }\end{array}$ & Poz-48514 & $4900 \pm 40$ & $3768-3635$ & 3682 \\
\hline \multirow[t]{2}{*}{$\overline{06 \mathrm{LJ}}$} & $\mathrm{MP} 172$ & Maharski prekop & $\begin{array}{l}\text { excavations } 1977, \\
\text { grid sq. } 47\end{array}$ & $\begin{array}{l}\text { food residue } \\
\text { on potery }\end{array}$ & Poz -4808 & $4940 \pm 40$ & $3794-3644$ & 3715 \\
\hline & & Maharski prekop & & wood & Z-314 & $4964 \pm 99$ & $3971-3533$ & 3766 \\
\hline 2OLJ & $\mathrm{MP} 211$ & Maharski prekop & $\begin{array}{l}\text { excavations 1970, } \\
\text { grid sq. 1-8 }\end{array}$ & $\begin{array}{l}\text { food residue } \\
\text { on potery }\end{array}$ & Poz-4866o & $4970 \pm 40$ & $3928-3652$ & 3746 \\
\hline$\overline{10 L J}$ & $\mathrm{MP} 46$ & Maharski prekop & $\begin{array}{l}\text { excavations } 1973 \text {, } \\
\text { grid sq. } 23\end{array}$ & $\begin{array}{l}\text { food residue } \\
\text { on potery }\end{array}$ & Poz-48513 & $4980 \pm 40$ & $3936-3654$ & 3756 \\
\hline \multirow[t]{2}{*}{$22 \mathrm{LJ}$} & MP151 & Maharski prekop & $\begin{array}{l}\text { excavations 1976, } \\
\text { grid sq. } 45\end{array}$ & $\begin{array}{l}\text { food residue } \\
\text { on potery }\end{array}$ & Poz-48526 & $5000 \pm 40$ & $3942-3693$ & 3782 \\
\hline & & Maharski prekop & $\begin{array}{l}\text { excavations } 1974, \\
\text { grid sq. } 42 \text {, pile } 156\end{array}$ & $\begin{array}{l}\text { wood } \\
\text { (Sorbus) }\end{array}$ & Z-351 & $5080 \pm 110$ & $4226-3646$ & 3872 \\
\hline$\overline{\mathrm{O} 3 \mathrm{LJ}}$ & $\mathrm{MP}_{144}$ & Maharski prekop & $\begin{array}{l}\text { excavations 1976, } \\
\text { grid sq. } 43\end{array}$ & $\begin{array}{l}\text { food residue } \\
\text { on potery }\end{array}$ & Poz-48504 & $5105 \pm 35$ & $3970-3798$ & 3868 \\
\hline$\overline{\mathrm{O}} \mathrm{LJ}$ & $\mathrm{MP} 224$ & Maharski prekop & $\begin{array}{l}\text { excavations 1976, } \\
\text { grid sq. } 43\end{array}$ & $\begin{array}{l}\text { food residue } \\
\text { on potery }\end{array}$ & Poz-48509 & $5180 \pm 40$ & $4219-3811$ & 3990 \\
\hline$\overline{\text { OgLJ }}$ & MP45 & Maharski prekop & $\begin{array}{l}\text { excavations } 1973 \text {, } \\
\text { grid sq. } 23\end{array}$ & $\begin{array}{l}\text { food residue } \\
\text { on potery }\end{array}$ & Poz- 48512 & $5210 \pm 40$ & $4224-3952$ & 4016 \\
\hline$\overline{12 L J}$ & MPg6 & Maharski prekop & $\begin{array}{l}\text { excavations 1974, } \\
\text { grid sq. } 34\end{array}$ & $\begin{array}{l}\text { food residue } \\
\text { on potery }\end{array}$ & Poz-48516 & $5270 \pm 40$ & $4230-3984$ & 4109 \\
\hline$\overline{18 \mathrm{LJ}}$ & $\mathrm{MP1}$ & Maharski prekop & $\begin{array}{l}\text { excavations 1970, } \\
\text { grid sq. 1-8 }\end{array}$ & $\begin{array}{l}\text { food residue } \\
\text { on potery }\end{array}$ & Poz-48522 & $5280 \pm 40$ & $4233-3989$ & 4120 \\
\hline $13 \mathrm{LJ}$ & $\mathrm{MP}_{174}$ & Maharski prekop & $\begin{array}{l}\text { excavations } 1977 \text {, } \\
\text { grid sq. } 60\end{array}$ & $\begin{array}{l}\text { food residue } \\
\text { on potery }\end{array}$ & Poz -48517 & $5310 \pm 40$ & $4256-3998$ & 4139 \\
\hline$\overline{\mathrm{O} 8 \mathrm{LJ}}$ & $\mathrm{MP} 25$ & Maharski prekop & $\begin{array}{l}\text { excavations } 1973 \text {, } \\
\text { grid sq. } 18\end{array}$ & $\begin{array}{l}\text { food residue } \\
\text { on potery }\end{array}$ & Poz-48510 & $5340 \pm 40$ & $4320-4045$ & 4171 \\
\hline$\overline{\mathrm{OlLJ}}$ & MP100 & Maharski prekop & $\begin{array}{l}\text { excavations 1974, } \\
\text { grid sq. } 37\end{array}$ & $\begin{array}{l}\text { food residue } \\
\text { on potery }\end{array}$ & Poz-485O2 & $5470 \pm 35$ & $4366-4242$ & 4327 \\
\hline \multirow[t]{2}{*}{$\overline{\mathrm{O} 2 \mathrm{LJ}}$} & $\mathrm{MP}_{121}$ & Maharski prekop & $\begin{array}{l}\text { excavations 1974, } \\
\text { grid sq. } 42\end{array}$ & $\begin{array}{l}\text { food residue } \\
\text { on potery }\end{array}$ & Poz-48503 & $5760 \pm 40$ & $4708-4502$ & 4612 \\
\hline & & Maharski prekop & grid sq. 34 & bone & Beta-219609 & $6570 \pm 40$ & $5615-5475$ & 5523 \\
\hline
\end{tabular}

Tab. 1. Radiocarbon dates for Maharski prekop. 


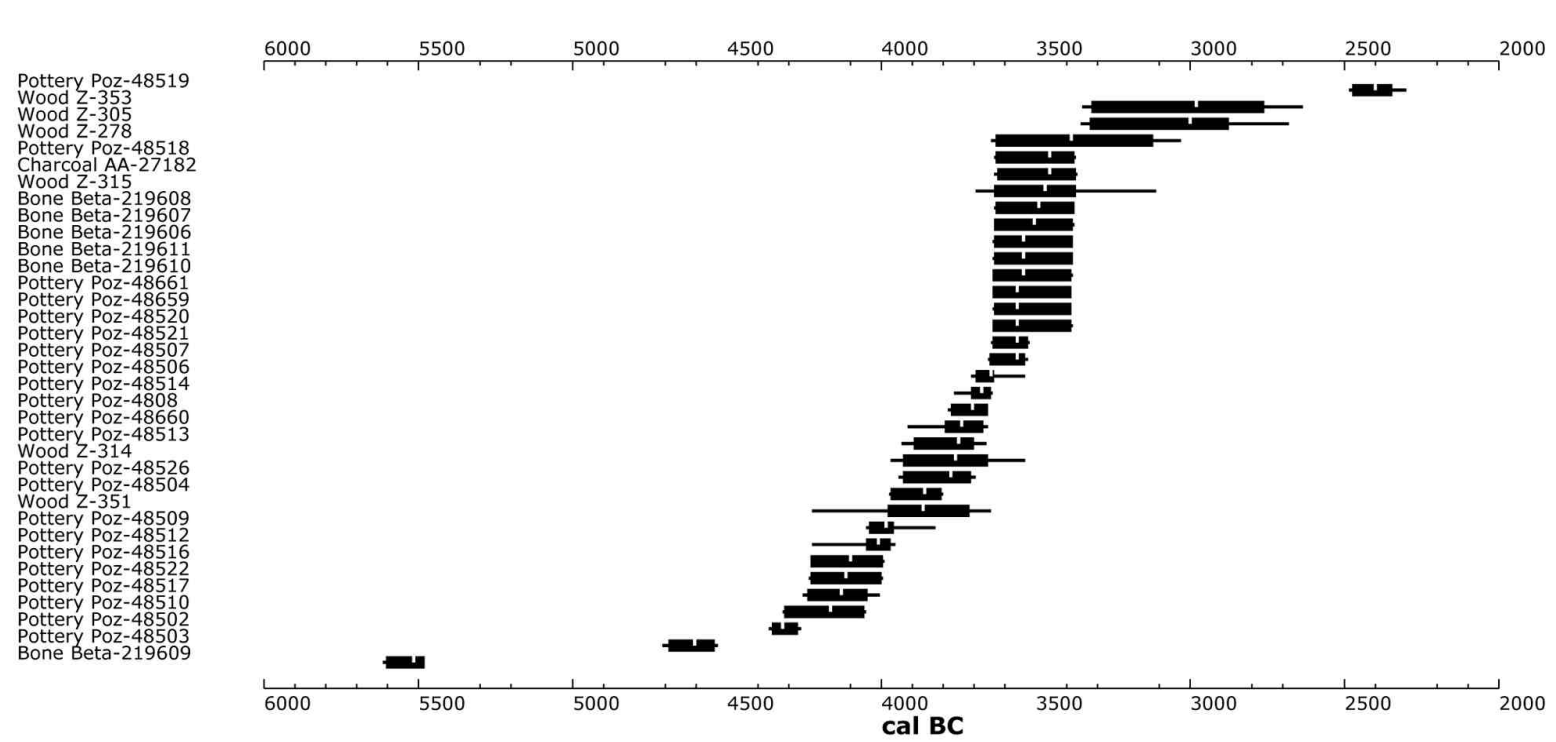

Fig. 2. Radiocarbon dates from Maharski prekop.

tion period between 3800 to 3550 calBC. The final spike after 3500 calBC can be attributed to a wiggle in the calibration curve between 3500 and 3400 calBC. These two concentrations are separated by a gap of around 200 years after 4000 calBC.

The oak chronology of 173 years from Maharski prekop is dated between 3661 and 3489 calBC ( $\breve{C}$ far et al. 2010). This corresponds well with the second concentration of radiocarbon dates presented above and indicates a period of intensive building and other activities at the site. However, a number of dates of carbonised food/organic residues are significantly older than suggested by the dendrochronological sequence. Thus at least 14 of the new dates obtained from pottery fall into the period between 4400 and $4000 \mathrm{calBC}$, suggesting intensive activities at the site at the time. This is further supported by two old dates of wooden piles that fall within this period.

Two intriguing older dates from Maharski prekop testify to sporadic activities at the site before the intensive occupation period between 4400 and 3550 calBC. Thus, one sample of animal bone yielded a date of 5615-5475 calBC, which makes it contemporaneous with the date from a Mesolithic site at Breg pri Škofljici (5843-5307 calBC). Additionally, one date of charred food/organic residues on pottery $(4708-4502$ calBC) is roughly contemporaneous with the dates from Resnikov prekop (Mlekuž, Budja and Ogrinc 2006.Tab. 1).

As already mentioned, the radiocarbon date of the organic infill of the palaeochannel (2833-2466 calBC) indicates the terminus ante quem for the palaeochannel located next to the site, suggesting that the palaeochannel silted up before that date. One date of carbonised food/organic residue on pottery from Maharski prekop comes immediately after this event, suggesting sporadic activities continued after the abandonment of the site.

These new dates suggest a much more complex chronological sequence for Maharski prekop than previously supposed. It appears that the site was settled for a much longer period, had distinct phases of occupation, and shows traces of earlier visits or activities. Therefore, new chronological sequence for Maharski prekop also has implications for the chronology of the microregion, as the gaps in the chronology are filled. Consequently, instead of a discrete, short-lived site, we are dealing with a node within a complex 'landscape of inhabitation'.

This exercise also shows the benefits of complementary dating methods and samples for a better under-

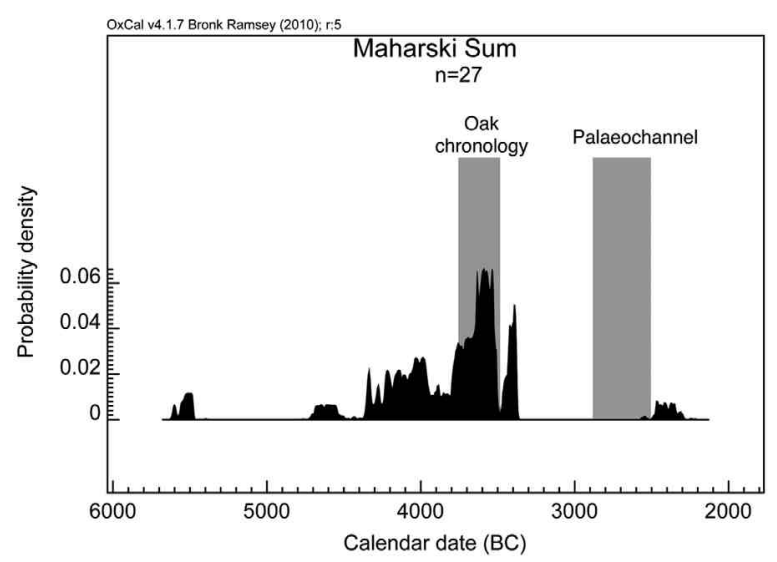

Fig. 3. Summed radiocarbon distribution of radiocarbon dates of food residues on pottery and bones from Maharski prekop. 
standing of the chronology of a site. The radiocarbon dates of bones and carbonised food/organic residues on pottery date events relating to the practices of preparation and disposal of food, and thus complement the dates of the wooden structures relating to events of building and construction.

\section{Spatial organisation}

Only such large-scale excavations offer an opportunity for a better understanding of the spatial structure of the sites. Thanks to the large area excavated by Tatjana Bregant, it is possible to assess the organisation of space within the Maharski prekop settlement. Bregant interpreted the site as a single-phase 'pile-dwelling' with several raised platforms where small houses were located (Bregant 1975.17-30).

The site was obviously located on a slightly raised area near an active

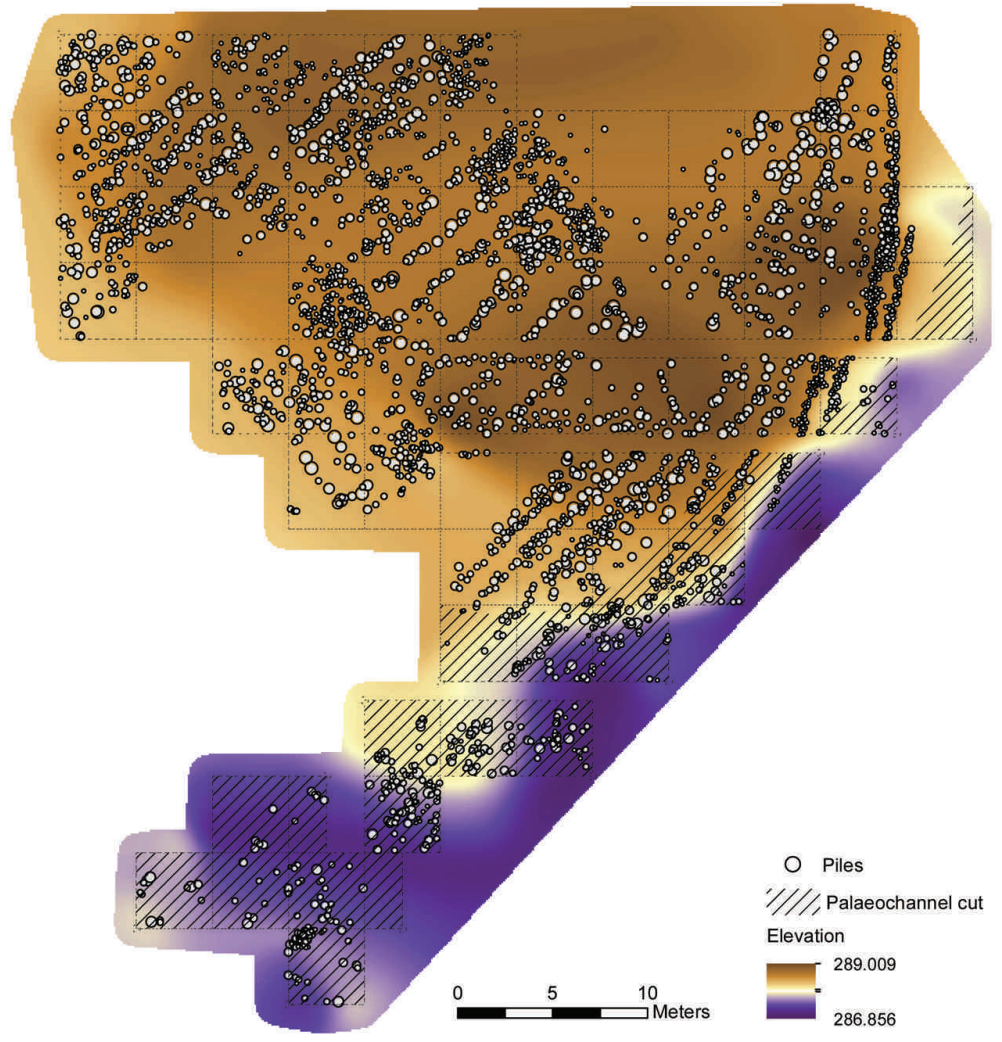

Fig. 4. The elevation of the original surface where piles were located at Maharski prekop. Note the palaeochannel on the eastern edge of the site. channel which runs to the east of the excavated area. A distinctive cut in the cultural layer is visible in the sections, which is the result of the erosion of the banks of the stream. In the southern part of the excavated area, further destruction can be observed in the lower density of piles and the lack of a cultural layer. This erosion can be identified on the lidar-derived digital elevation model as a low terrace associated with the modern Ižica River. The central, western and northern parts of the site were not damaged by erosion (Fig. 4).

During the excavation, 2432 vertical wooden piles were recorded at the site. The average vertical pile density is almost 2 piles per $\mathrm{m}^{2}$ and the arrangement of piles displays a regular pattern. Over most of the undisturbed part of the activated area, piles are usually organised in sets of three parallel rows. Most of the rows were oriented parallel to the documented palaeochannel. The mean pile diameter is $5.8 \mathrm{~cm}$ (standard deviation $3.8 \mathrm{~cm}, \mathrm{~N}=1743$ ), although piles with diameters of up to $26 \mathrm{~cm}$ have been found. Piles with larger diameters were often split, and comprise $28 \%$ of all piles. The piles were usually made of three types of wood, oak (Quercus), ash (Fraxinus), and rowan (Sorbus) and comprise more than $90 \%$ of the identified taxa ( Sercelj 1973;
1975). Some of the recovered piles were very long, as they were driven up to $3 \mathrm{~m}$ into the silt (Bregant 1974b.43).

This arrangement of piles can be interpreted as the remains of nine houses with dimensions of around $10 \times 3.5-4.5 \mathrm{~m}$ arranged in parallel. Each house is therefore made of three rows of structural timbers, with a central row of centre-posts supporting a roof ridgepole, while lateral the rows are wall posts. Most of the houses are oriented with the longer side parallel to the channel. Only one of the houses is oriented at right angle to the others (Fig. 5).

Based on the relative height of the piles, we can divide the settlement into two building phases. When the superstructure was destroyed (either by fire, flood or decay), only parts of the posts below the occupational surface survived. Thus the heights of the recovered piles may indicate the levels of occupational floors at the time when the houses were destroyed. Since the original surface of the settlement was irregular, we cannot compare the heights of the remaining piles directly, but we can relate them to the surface of the cultural layer that was interpolated from the published sections. Piles with tops below the surface of the cultural layer were the- 
refore part of older structures than the piles extending above the cultural layer. In this way, two phases of the settlement, an older and younger phase, can be identified (Fig. 6). Piles from both phases are not distributed randomly; instead, piles from the same phase tend to be clustered in groups that we have identified as houses. This supports our interpretation of pilerows as the remains of houses, and enables us to subdivide the houses themselves into chronological phases (Mlekuž, Budja and Ogrinc 2006).

However, a number of piles could not be linked to houses at Maharski prekop. Some thin piles located within the settlement area can be associated with less permanent wooden structures such as drying racks or fences. But the most obvious structures were two or three dense rows of piles running along the channel on the eastern side of the excavated area. The piles in these structures were generally of

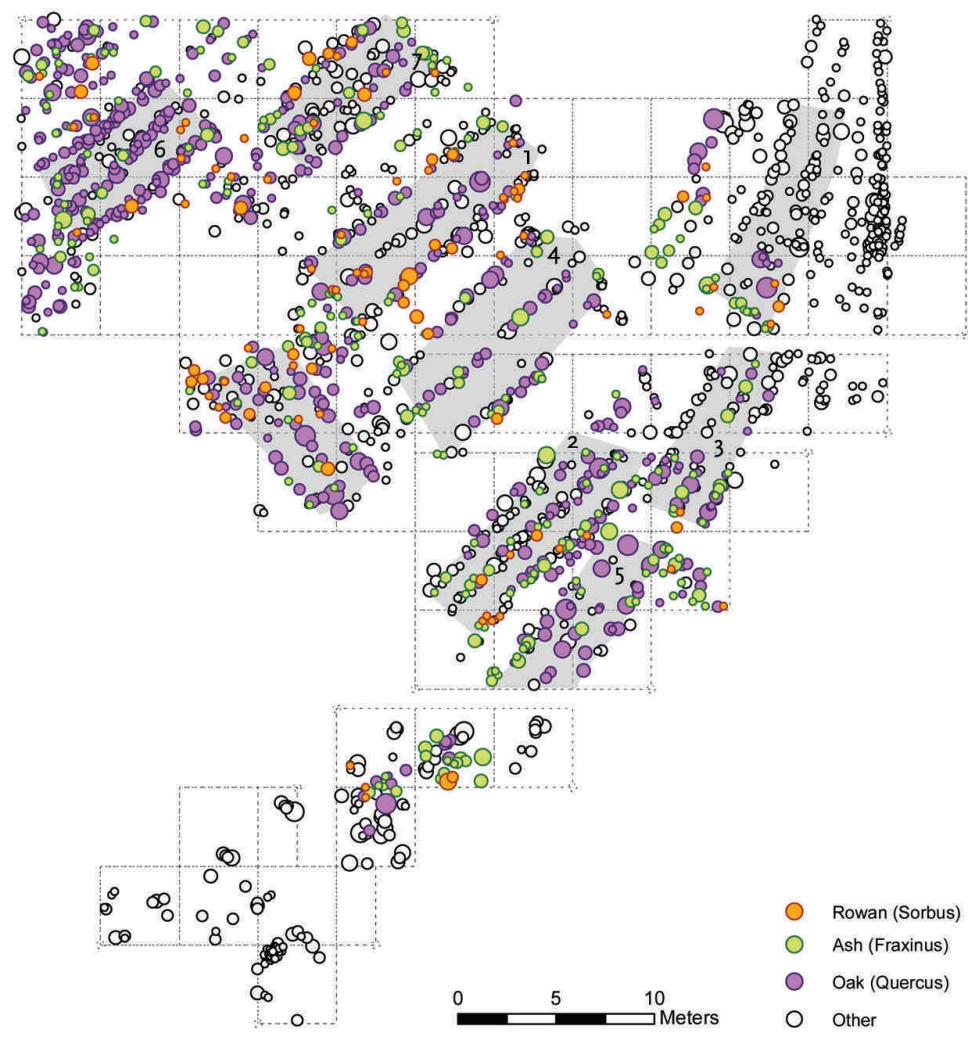

Fig. 5. Distribution of piles, choice of wood and reconstructed house plans at Maharski prekop. much smaller diameters than those in the central part of the excavated area, and split piles are almost non-existent. The type of wood used for these piles was much more diverse than in the piles of the cen-

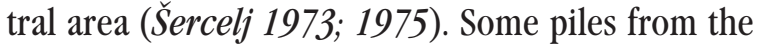
easternmost row were inclined towards the channel, which obviously eroded the cultural layer. The excavator interpreted these structures as a revetment (Bregant 1975.17-20, Fig. 1), which supports the evidence of the active paleochannel associated with the site.

Clay surfaces that were often burned were also recorded within the cultural layer (Bregant 1974b. 12; 1975.14-15). They could be up to $20 \mathrm{~cm}$ thick, and covered large areas between the rows of piles, and in some cases their direct stratigraphic superposition could be observed. For example, in the southern part of the excavated area, there is evidence of the superposition of two clay floors separated by a thin layer of occupational debris, which could indicate the periodic rebuilding of surfaces (Fig. 7). Concentrations of stones are another common feature of the site (Bregant 1974a.12; 1974b.41; 1975.14-15). Stones form distinctive clusters or features that were commonly found at the peripheral ends of houses. Stones were sometimes distributed along lateral rows of piles and are often associated with lenses of charcoal, indicating that they could be interpreted as remnants of thermal structures. The concentrations of stones are also often associated with grindstones.

Additionally, around $224 \mathrm{~kg}$ of pottery were collected at the site, and the position of 131 other types of artefacts (such as axes, spindle whorls, bone tools, loom weights, personal ornaments, cooper metallurgy implements etc.) was recorded during the excavation (Fig. 8). Based on the assumption that the 'cultural layer' represented a short-term occupation of the site, the excavator recorded the spatial position of artefacts only within $4 \times 4 \mathrm{~m}$ grid squares. Therefore, the stratigraphic position of artefacts within the 'cultural layer' is lost, compelling us to treat the artefacts as only a single spatial distribution over the site.

Most of the material enters the archaeological record through depositional practices that have a clear spatial dimension. Artefacts discarded at their locations of use are termed primary refuse; those discarded elsewhere are known as secondary refuse. The primary refuse is rare, since we tend to clean our living and working areas. An unmistakable characteristic of secondary refuse distributions in most settlements is clustering. People tend to dump refuse some 
distance from where it was produced, and where others have previously dumped refuse, producing concentrations. The distribution of pottery at Maharski prekop is clustered. We can observe at least three distinct concentrations: one in the palaeochannel in the southern part of the site; in the central part of the site; around old phase house 1 and between new phase houses 2, 4 and 5 . The distribution of other material generally follows the distribution of pottery, with some differences. There is a large concentration of bone axes in front of house 1, together with concentrations of stone, pottery and flint tools. Spindle whorls are concentrated in the empty space between houses 4 and 2; here, personal ornaments and finds associated with metallurgical activities were also recovered. On the other hand, bone tools are concentrated in the paleochannel together with pottery (Fig. 8).

At long-term settlements, we cannot assume any direct relation between structural remains and artefact distribution. Michael Schiffer's (1987; LaMotta, Schiffer 1997) work on the formation processes of the archaeological record demonstrated that what we see in an archaeological record is the result of the process of building, use, abandonment, and post-abandonment transformations often operating together,

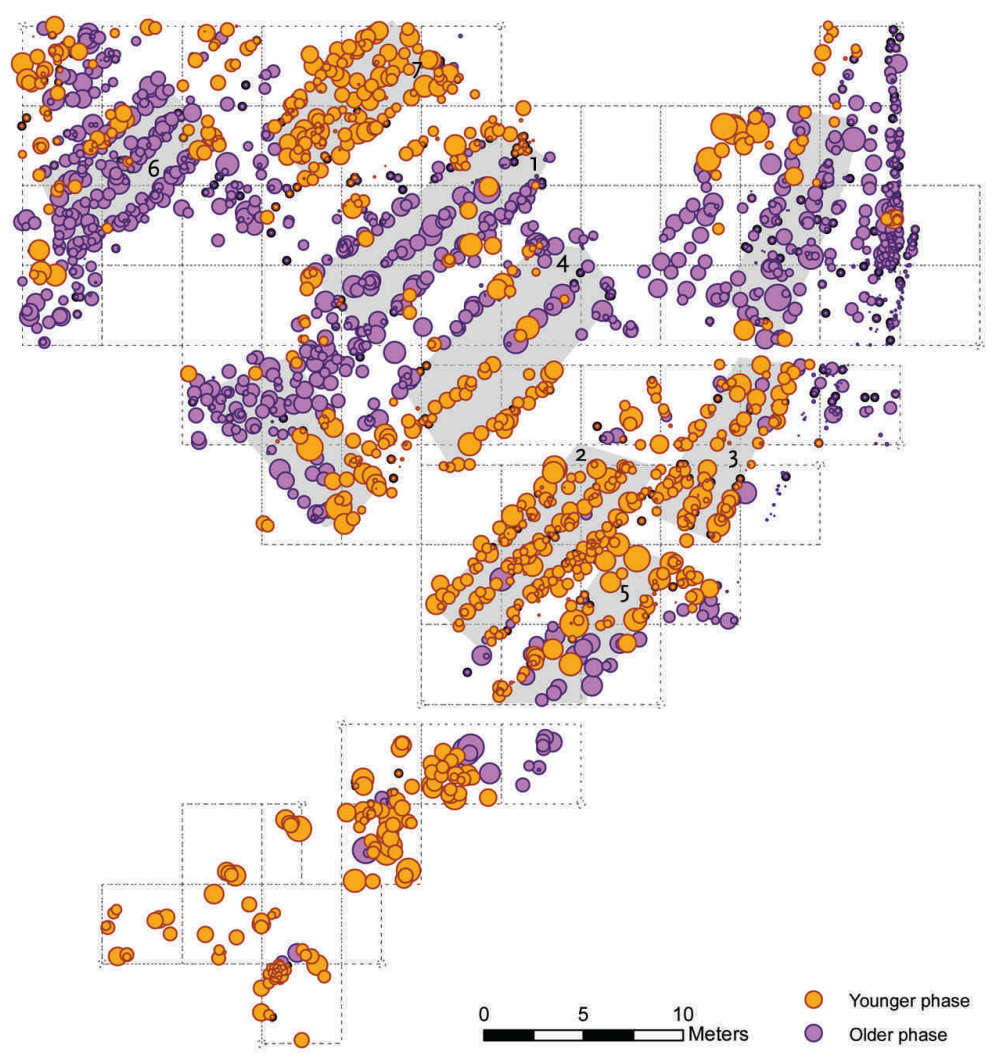

Fig. 6. Division of piles and houses into chronological phases based on the relative heights of the piles at Maharski prekop. making artefact distribution a complex palimpsest of various formation processes.

\section{Pottery at Maharski prekop}

Pottery studies have been dominated by detailed analyses of decorative motifs and the construction of elaborate chronological schemes. However, pots are made to be used. In most cases, the primary functions of ceramic vessels are processing, storing, transporting, serving, and consuming foods and liquids (Rice 1987.207-208). The potter makes technical choices related to performance in manufacture and use in accordance with the vessel's intended functions, controlling the shape and size of the vessels, paste characteristics, firing conditions, and surface treatments to create vessels for specific purposes (Skibo 1992.27-56; DeBoer 1984; Tite 2008; van As 1984). The shape, size and capacity of a vessel are likely to relate very closely to the different potential functions of the pot (Rice 1987.207).

Marion Smith (1988) found three measures, 'morphological correlates of use', that are particularly relevant when correlating form to function. The first is the relative openness of the vessels, which is the ratio of the circumference of the rim to the total external surface area; the second is the diameter of the vessel rim and the third is capacity of the vessel. Using a cross-cultural approach, he isolated several interesting correlations between these measures and intended functions of the vessel. Thus, rim size is proportional to the extent that the contents of a vessel are changed. The serving of liquids or solids correlates with rim forms that do not curve inward. Rim diameter is inversely proportional to the duration of storage time. Vessels that require access to contents during use will have an opening big enough for hand access. Vessels used to transport liquids have a small opening. On the other hand, Prudence Rice (1987.224-226) identified four loosely defined performance characteristics related to vessel shape: capacity, stability, accessibility, and transportability. These attributes are not defined mathematically, but are nevertheless useful in describing the properties of a vessel in relation to intended use. Other 
technological choices are also closely related to the intended use of the pot. Thus the choice of a particular temper, paste characteristics and firing conditions might have an impact on how a vessel performs during manufacture and use (Braun 1983; DeBoer 1984; Skibo 1992.2756). Technological properties such as thermal shock resistance, and heating effectiveness might thus be highly related to the intended function.

\section{Pottery typology and use}

Our approach to the pottery assemblage from Maharski prekop (Bregant 1974a; 1974b; 1975; with unpublished material from excavations in 1976 and 1977) is characterised by a focus on whole pots rather than individual sherds. During the initial analysis of the pottery assemblage, 476 reconstructed or partly reconstructed pots were defined. Vessel form was described with the

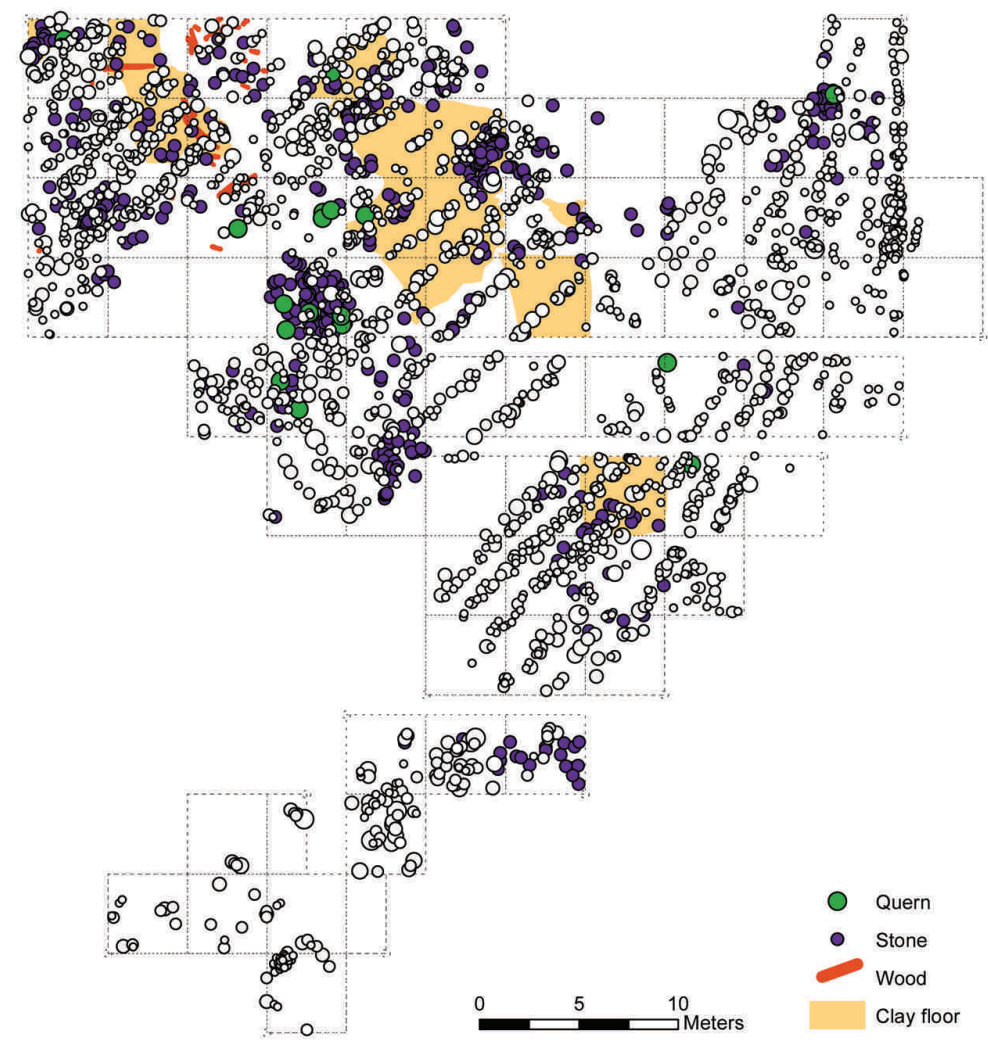

Fig. 7. Distribution of stone features, querns, clay floors and wood fragments at Maharski prekop. formal parameters defined by Milena Horvat (1999), and the capacity, openness and rim diameter were estimated for 349 vessels. Openness was defined as the ratio between orifice area and external surface area. The vessels were then arranged along three dimensions: capacity, openness and rim diameter. The rim diameter and capacity highly correlate; therefore, the relation between the vessel's openness and capacity was established to be most informative. Based on these criteria, we divided the corpus of vessels into 5 vessel groups. Most of the vessels have low capacity, below 4 litres, with the peak between 1 and 2 litres; however, there are some very large vessels with volumes up to 100 litres (Tab. 2; Fig. 9-10).

(1) The first vessel group consists of small pots, usually with a capacity less than 0.5 litres. The relative openness ranges from low to moderate, while rim diameters are highly uniform, as they fall between 5 and $10 \mathrm{~cm}$. The low capacity, low rim diameter and moderate openness suggest that these vessels might have been used for the individual consumption of liquids.

(2) The second group consists of vessels with very high to extreme openness. The vessel capacity ranges between 0.5 and 20 litres, although most have a capacity below 4 litres. Rim diameters are very large and the vessels are mostly shallow, indicating very high accessibility and stability. These vessels might have been used for the individual consumption of food (in the case of low capacity vessels) and communal serving vessels (in the case of high capacity vessels).

3 The third group consists of vessels with lower rim diameters and moderate openness. Vessel capacity ranges between 0.5 and 20 litres; most of the vessels have a capacity below 10 litres. These vessels are usually of globular shape, with moderate accessibility. Their intermediate openness and accessibility - between groups 2 and 4 - suggest a variety of functions.

(4) The fourth group consists of vessels with lower rim diameters and low openness. These vessels are usually deep and have low accessibility. Volumes up to 20 litres indicate that they could be used for the preparation of full meals. However, most of the vessels have capacities around 1 litre, indicating that only certain parts of a meal could have been stirred and cooked in such pots.

5 The fifth group consists of a few vessels with an extreme capacity above 20 litres. The vessels in this group have low openness; they are deep and inac- 
cessible. Their large capacity and accessibility suggest that they can be interpreted either as very large food preparation and processing vessels or vessels for temporary storage.

The vessels from Maharski prekop display a broad range of size and/or form classes associated with a variety of inferred functions. The variety of vessel forms and sizes suggests that the site served as a locus of diverse subsistence processing, storage, and consumption activities. There is a general lack of vessels with very low accessibility (low rim diameter and low openness) that could be interpreted as long-term storage vessels. Capacities that peak between 0.5 and 2 litres suggest that most of the assemblage consists of vessels for the individual consumption of food or food preparation for small groups of people. This suggests individual consumption, which can be defined as when not only the eating of food is done from individual vessels, but also the serving (Bats

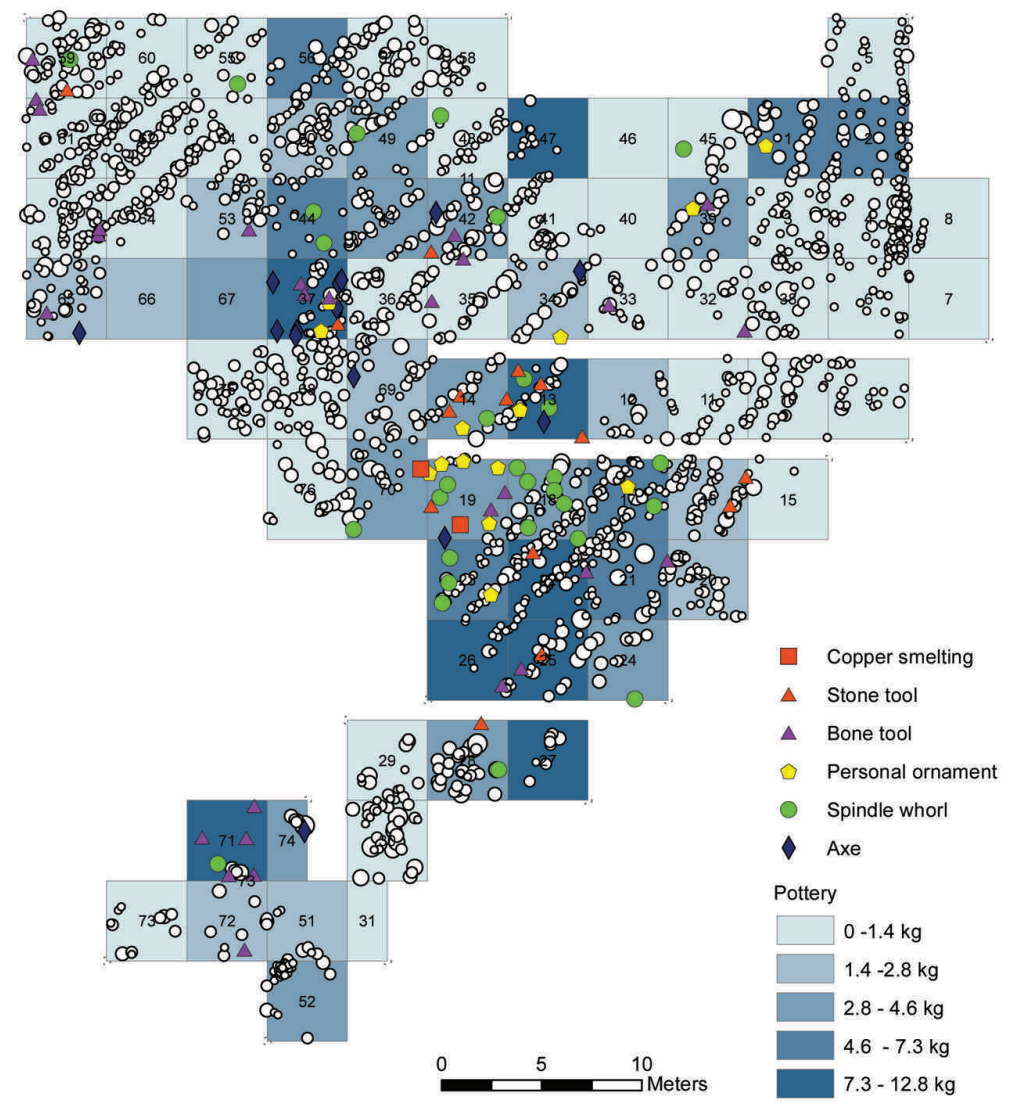

Fig. 8. Distribution of pottery and other material at Maharski prekop.
1988.23). However, the presence of some very large vessels that could be used for food preparation or serving suggest that communal food preparation and consumption was at least sporadically practiced.

The direct evidence of vessel use can survive in the form of external soot or as burnt food residues on the surface, and animal fats and plant waxes absorbed by the pottery. In the assemblage from Maharski prekop, 39 vessels with organic residues were identified. If we interpret these residues as traces of burnt food, and therefore an indication of cooking, then they can give further insight into the use of pottery. Organic residue is completely absent in groups 1 and 2, further supporting the hypothesis that these vessels were not used for cooking, but for the consumption of food. Most of the food residue is present in group 3, especially in the vessels with a capacity below 5 litres, which further supports our observation that most of the cooking at Maharski prekop was done on a small scale, either for very small groups of people, or that only elements of a larger meal may have been cooked in individual pots. However, organic residues are present on some very large vessels in group 5 with capacities up to 80 litres, indicating that cooking or processing of large quantities of food was sporadically practiced (Fig. 9).

Pottery samples with charred organic residue on the internal surface of the vessels were AMS radiocarbon

\begin{tabular}{|llccccc}
\hline & Definition & Size & $\begin{array}{c}\text { Organic } \\
\text { residue }\end{array}$ & $\begin{array}{c}\text { Median } \\
\text { capacity } \\
\text { (in litres) }\end{array}$ & $\begin{array}{c}\text { Median rim } \\
\text { diameter } \\
\text { (in cm) }\end{array}$ & $\begin{array}{c}\text { Median } \\
\text { openess }\end{array}$ \\
\hline Group 1 & Capacity less than 0.5 & 13 & 0 & 0,24 & 7,7 & 0,31 \\
\hline Group 2 & Capacity between 0.5 and 20l, very open & 14 & 0 & 2,72 & 22 & 0,42 \\
\hline Group 3 & Capacity between 0.5 and 20l, moderately open & 63 & 5 & 4,96 & 21,6 & 0,31 \\
\hline Group 4 & Capacity between 0.5 and 20l; closed & 176 & 16 & 7,00 & 20 & 0,21 \\
\hline Group 5 & Capacity more than 20 I & 36 & 4 & 33,89 & 35,8 & 0,21 \\
\hline
\end{tabular}

Tab. 2. Vessel use groups of pottery from Maharski prekop. 
dated (see above), but were also analysed for their lipid content with a series of different methods and techniques (as presented by Ogrinc et al. this volume). Lipids are exceptionally well preserved, since among 20 analysed samples only 5 yielded no lipids, and the remainder include a wide range of identified foodstuffs. Most of the samples provided evidence of animal fats (including cattle adipose fats), and there is also a large number of samples with evidence of mixed animal and plant fats. Two samples also yielded evidence of milk. At present, 13 samples can be linked to individual vessels; their capacity ranges from 1 to 51 litres; vessels were classified into groups 3, 4 and 5 (Tab. 3).

\section{Pottery technology}

For the study of pottery technology of the Maharski prekop assemblage, samples from different types of vessels from a series of grid squares were chosen for analysis. The study included a hand specimen description of the pottery where different fabric types were identified (following Horvat 1999) and later a petrographic analysis of pottery thin sections (following Whitbread 1995.365-396; Terry, Chillingar 1955). The fabric groups were defined according to the origin of the clay and ceramic recipe, which includes the presence of temper in the fabric. Temper is distinguished from naturally occurring inclusions with the aid of various criteria, including grain-size distribution, roundness, angularity, sorting, and mineralogical composition (Rice 1987.409-411; Whitbread 1995.393).

At Maharski prekop, we selected 222 pottery samples, of which more than $70 \%$ come from typologi- cally defined vessels and from all five of the vessel groups (see above). The hand specimen analysis of Maharski prekop pottery showed great uniformity of fabrics and recipes. We identified 4 different fabric types: fabric 1 with abundant calcite inclusions (in the fine sand to gravel fraction); fabric 2 with inclusions of calcite and grog; fabric 3 with fine-grained quartz inclusions and organic material; and fabric 4 with abundant coarse-grained quartz. The majority of vessels were made with fabric 1 , which is characteristic of $95.9 \%$ of the pottery analysed. Fabric 2 with inclusions of calcite and grog in the paste, as well as fabric 4 with quartz, were present in less than $1 \%$ of the samples, while fabric 3 with quartz and organic matter was present in $3 \%$ of the samples. The pottery from Maharski prekop was mostly fired in a reducing or not fully oxidised atmosphere; the most common surface colour is dark grey, and the pottery is mostly soft. These characteristics give the pottery assemblage a very homogenous appearance.

Pottery samples from fabric groups 1, 2 and 3 were also prepared for thin section analysis by polarising microscope. The results of the petrographic analysis show that the mineralogical composition of these samples is mostly comprised of calcite, quartz, chert, muscovite and biotite micas, dolomite, plagioclase feldspars, opaque concentration features and organic material (Tab. 4). 1 The main differences between the fabric groups are mostly based on the various materials added as temper. Fabric 1, the most common fabric group among the Maharski prekop pottery, is identifiable mostly by the presence of added monocrystalline calcite as temper and the presence

\begin{tabular}{|c|c|c|c|c|c|}
\hline $\begin{array}{l}\text { Sample } \\
\text { no. }\end{array}$ & Sample description & $\begin{array}{l}\text { Vessel } \\
\text { group }\end{array}$ & $\begin{array}{l}\text { Rim diameter } \\
\quad \text { (in } \mathrm{cm})\end{array}$ & $\begin{array}{l}\text { Capacity } \\
\text { (in litres) }\end{array}$ & $\begin{array}{l}\text { Predominant } \\
\text { commodity type }\end{array}$ \\
\hline$\overline{\mathrm{MP} 25}$ & absorbed food residue in pottery & 4 & 17 & 4.2 & mixture \\
\hline $\mathrm{MP} 45$ & absorbed food residue in pottery & 4 & 11.4 & 1 & ruminant goat milk \\
\hline $\mathrm{MPg6}$ & absorbed food residue in pottery & 3 & 33.9 & 19 & plant \\
\hline MP100 & absorbed food residue in pottery & 5 & 39 & 52.9 & ruminant cattle adipose fat \\
\hline$\overline{M P 121}$ & absorbed food residue in pottery & 3 & 28 & 13.1 & mixture \\
\hline $\mathrm{MP}_{144}$ & absorbed food residue in pottery & 4 & 17.6 & 4 & $\mathrm{n} / \mathrm{a}$ \\
\hline $\mathrm{MP} 158$ & absorbed food residue in pottery & 4 & 25.6 & 17.2 & ruminant cattle adipose fat \\
\hline $\mathrm{MP} 158 \mathrm{a}$ & charred organic residue on vessel surface & 4 & 25.6 & 17.2 & ruminant adipose fat \\
\hline $\mathrm{MP} 174$ & absorbed food residue in pottery & 5 & 31.8 & 32.6 & plant \\
\hline $\mathrm{MP}_{211}$ & absorbed food residue in pottery & 5 & 33.6 & 33.9 & mixture \\
\hline MP85 & charred organic residue on vessel surface & 5 & 39.2 & 51 & plant \\
\hline$\overline{\mathrm{MP}} 181$ & charred organic residue on vessel surface & 4 & 26.2 & 18 & plant \\
\hline
\end{tabular}

Tab. 3. Vessels with the results of lipid analyses from Maharski prekop (see also Ogrinc et al. this volume).

112 pottery samples from Maharski prekop were already partly analysed in the 1970's using a reflected light microscope, x-ray diffraction and differential thermal analysis (Osterc 1975). Most of them had a similar composition to our fabric group 1 with calcite added as temper and one of the samples had added grog characteristic for fabric 2 (Osterc 1975.124-125). No samples belonging to fabric groups 3 or 4 were described in Osterc's this study. 


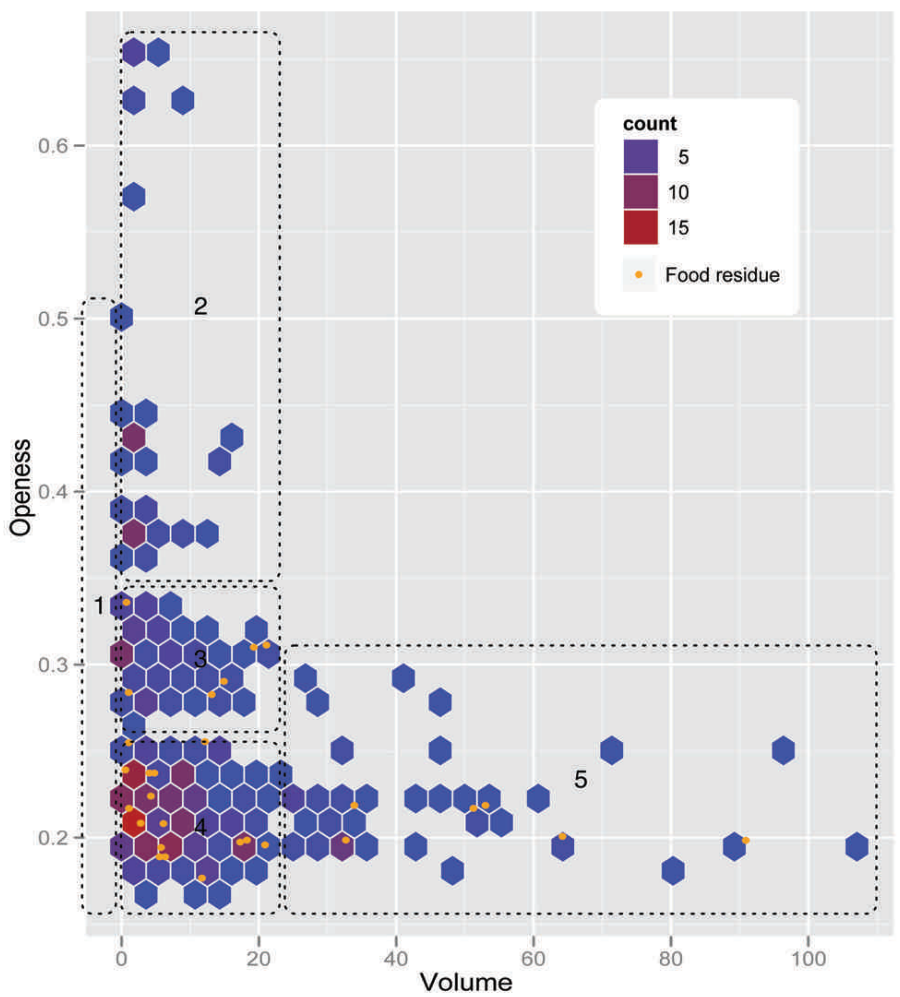

Fig. 9. Vessels from Maharski prekop, arranged according to their capacity and openness. Vessel use groups are indicated.

of biotite mica and rare dolomite grains among the naturally present inclusions. The main difference between the samples is the relative abundance and coarseness of the artificially added calcite grains. The vessels made with this fabric come from a variety of contexts inside Maharski prekop and can be attributed typologically and according to the radiocarbon dates to all phases at the site. Fabric 2 was identified in only 2 pottery samples, its main characteristic being the addition of crushed pottery or grog temper alongside monocrystalline calcite. The grog in fabric 2 has the same composition as fabric 1 pottery, which proves that the potters reused old and used, or perhaps destroyed, pots. The natural inclusions of fabric 2 are mostly similar to the composition of fabric 1. Fabric 3 was identified in 6 samples in hand specimen analysis, and only one of the samples was prepared as thin section. The main characteristic of this fabric is organic material added as temper that was mostly burned out during firing, leaving irregularly shaped voids, although some was still present in the paste. The natural composition of this fabric differs significantly from fabrics 1 and 2, since no chert, biotite or plagioclase feldspars were present in the natural paste.

The petrographic results and the results of the X-ray diffraction of clays collected near Maharski prekop at the Gornje mostišč location suggest that the naturally occurring raw materials have a comparable mineralogical composition to the pottery samples. The clays are mostly composed of monocrystalline and polycrystalline quartz, dolomite, muscovite and biotite mica, chlorite and plagioclase feldspars. The Pleistocene sediments in Ljubjansko Barje such as gravel, sands, silts and clays were mostly transported to this area by rivers such as Ižica, and the sedimentological analysis of sediments from the nearby archaeological site of Resnikov prekop showed that grains larger than $2 \mathrm{~mm}$ were composed mostly of limestone, with rare tuff, sandstones, dolomite and chert (Turk 2006.94-96). From these results, we conclude that the clays for pottery production at Maharski prekop were collected locally on the Ižica floodplain; only calcite used as tempering material was probably collected on the karstic periphery of Ljubljansko Barje, where it could be collected from veins, druses and speleothems in caves (Gams 2004.361-369).

If we compare the fabric groups to the vessel groups, we observe that the most common fabric with calcite temper was used for creating all types of vessels, from small pots of less than 0.5 litres to large vessels of more than 20 litres. Only some vessels with lower rim diameters and low openness from the fourth group and the largest vessels from the fifth group were partly made with fabrics with added grog or organic material.

\section{Conclusions}

The production of pottery is closely related to a range of human activities: the transportation, stor-

\begin{tabular}{|lccccccc|}
\hline Fabric group & Number of samples & Grid square & Calcite $\%$ & Quartz $\%$ & Mica $\%$ & Grog $\%$ & Organic material \% \\
\hline Fabric 1 & 6 & $1-8,17,18,37$ & $20-30 \%$ & $5-10 \%$ & $1-5 \%$ & 0 & less than $1 \%$ \\
\hline Fabric 2 & 2 & 13 & $10-20 \%$ & $5-10 \%$ & $5 \%$ & $5-10 \%$ & less than $1 \%$ \\
\hline Fabric 3 & 1 & 44 & 0 & $5 \%$ & $2 \%$ & 0 & $3 \%$ \\
\hline
\end{tabular}

Tab. 4. The basic mineralogical composition of pottery fabric groups from Maharski prekop. 
age, preparation, cooking and consumption of food. However, the interactions between the chaîne opératoire of pottery manufacture and the chaine opératoire of food preparation and consumption are not straightforward. While vessel shape and fabric may suggest the intended function, the analysis of preserved lipids in pottery indicates what was actually cooked, boiled, stored or processed in the vessels. Interpretation is made even more difficult by the fact that the same vessels may have been used for different purposes, or may have been reused after being considered no longer fit for their intended function (Rice 1987.207-208).

The pottery assemblage from Maharski prekop is characterised by a large variability of vessels both in terms of their forms and dimensions. Five vessel groups were defined in our analysis; nevertheless, inter-group variability is also high. This variability can be explained by the non-specialised use of vessels, where they were deliberately designed to be able to perform a series of different functions. This is further supported by the technological analysis of fabrics. The identified fabric groups are very similar: pots were made using one general recipe characterised by the presence of added calcite as temper. No significant differences appear between vessel-use groups in terms of the presence of specific fabric groups. The differences between the three defined fabric groups cannot be explained by technological choices, but different traditions or individual idiosyncrasies. The generalised fabric recipe suggests that the intended use of a vessel was not predetermined during its manufacture.

Food residues on vessels, indicating that a vessel was used for cooking, are present on a wide range of vessels regardless of their capacity, openness or form. Food residues are absent only in groups 1 and 2 , which were interpreted as vessels used for the individual consumption of food. Therefore, vessel groups 3, 4 and 5 could have been used for different purposes, including processing, temporary storage and serving of foodstuffs. The diversity and nonspecialised use of pottery observed in the Maharski prekop assemblage is consistent with the analysis of lipids. The small number of analysed samples analysed thus far does not allow strong correlations between vessel shape and dimensions and their actual use for cooking. At the moment, 13 samples can be linked to individual vessels, their capacity ranging from 1 to 51 litres. The range of identified foodstuffs is also wide, since at least five samples have been identified as corresponding to a mixture of fatty acids (see Ogrinc et al. this volume). Therefore, the vessels at Maharski prelop were used for a variety of inferred purposes. No specialised vessels can be linked to a single function - the exceptions being groups 1 and 2, which can be interpreted as vessels for individual consumption.

In terms of the spatial distribution of the pottery, we were able to observe some clustering on the site. However, this clustering cannot be interpreted in terms of specific activities or the spatial organisation of activities connected to pottery use. It is naive to expect that the artefact distribution would reveal a functional division of the structures at Maharski prekop. Instead, artefact distribution should be seen as a material residue of long-term mundane practices, such as cleaning, dumping and abandonment, as well as post-depositional modifications, which at Maharski prekop are mostly associated with water erosion. What the artefact distribution does not reflect is a frozen snapshot of social organisation, revealing functional variations within the site. Dumping activities - with their large quantities of material produced - and abandonment processes are the most likely sources of major artefact variation, although the effect of functional variation cannot simply be dismissed. Thus, we can observe patterns at Maharski prekop that are the result of long-term processes of use, dumping and abandonment, which cannot be simply interpreted as a single event or a functional division of the site. The phasing of houses, the thickness and stratigraphic relations between features in the 'cultural layer', and the wide range of radiocarbon dates from the site further support the idea that Maharski prekop was a long-term and complex site. 
The research was undertaken as part of research projects J6-4085 (Mihael Budja), J6-4016 (Dušan Plut), and research programme P6-0247 (Mihael Budja) funded by the Slovenian Research Agency. We thank the Ljubljana City Museum and our colleague Irena Šinkovec for providing access to the Maharski prekop pottery assemblage.

\section{References}

van As A. 1984. Reconstructing the potter's craft. In S. E. van der Leeuw and A. C. Pritchard (eds.), The many dimensions of pottery: Ceramics in archaeology and anthropology. University of Amsterdam, Amsterdam: 129164.

Bats M. 1988. Vaisselle et alimentation à Olbia de Provence (v.350-v.50 av. J.C.). Modeles culturels et categories ceramiques. Revue Archeologique de Narbonnaise, Supplement 18. Centre National de la Recherche Scientifique. Paris.

Bregant T. 1964. Poročilo o raziskovanju kolišča in gradbenih ostalin ob Resnikovem prekopu pri Igu. Poročilo o raziskovanju neolita in eneolita $v$ Sloveniji 1: 7-24.

1974a. Kolišče ob Maharskem prekopu pri Igu - raziskovanja leta 1970. Poročilo o raziskovanju neolita in eneolita Slovenije 3: 7-34.

1974b. Kolišče ob Maharskem prekopu pri Igu - raziskovanja leta 1972. Poročilo o raziskovanju neolita in eneolita Slovenije 3: 39-66.

1975. Kolišče ob Maharskem prekopu pri Igu - raziskovanja 1973. in 1974. leta. Poročilo o raziskovanju neolita in eneolita Slovenije 4: 7-106.

Braun D. P. 1983. Pots as tools. In A. Keene and J. Moore (eds.), Archaeological hammers and theories. Academic, New York: 107-134.

Budja M. 1994/1995. Spreminjanje naravne in kulturne krajine $\mathrm{v}$ neolitiku in eneolitiku na Ljubljanskem barju I. Poročilo o raziskovanju paleolitika, neolitika in eneolitika v Sloveniji 22: 163-181.

1997. Landscape changes in the neolithic and copper ages in Slovenia. Case study: the Ljubljansko Barje region. In J. Chapman, P. M. Dolukhanov (eds.), Landscapes in Flux: Central and Eastern Europe in antiquity. Colloquia Pontica 3. Oxbow books, Oxford: 7788.

Budja M., Mlekuž D. 2008. Settlements, landscape and palaeoclimate dynamics on the Ižica floodplain of the Ljub- ljana Marshes. In M. Budja (ed.), 15th Neolithic Studies. Documenta Praehistorica 35: 45-54.

2010. Lake or floodplain? Mid-Holocene settlement patterns and the landscape dynamic of the Ižica floodplain (Ljubljana Marshes, Slovenia). The Holocene 20 (8): 1269-1275.

Čufar K., Kromer B., Tolar T. and Velušček A. 2010. Dating of $4^{\text {th }}$ millennium BC pile-dwellings on Ljubljansko barje, Slovenia. Journal of Archaeological Science 37/8: 2031-2039.

DeBoer W. 1984. The last pottery show: System and sense in ceramic studies. In S. E. van der Leeuw and A. C. Pritchard (eds.), The many dimensions of pottery. University of Amsterdam, Amsterdam: 527-571.

Gams I. 2004. Kras v Sloveniji v prostoru in času. Založba ZRC. ZRC SAZU. Ljubljana.

Harej Z. 1978. Kolišče v Partih pri Igu na Ljubljanskem barju. Poročilo o raziskovanju paleolita, neolita in eneolita 6: 61-94.

1981. Kolišče v Partih pri Igu na Ljubljanskem barju. Poročilo o raziskovanju paleolita, neolita in eneolita v Sloveniji 9-10: 31.101.

1987. Kolišče v Partih pri Igu na Ljubljanskem barju raziskovanja leta 1981. Poročilo o raziskovanju paleolita, neolita in eneolita v Sloveniji 15: 141-194.

Horvat M. 1999. Keramika: tehnologija keramike, tipologija lončenine, keramični arhiv. Znanstveni inštitut Filozofske fakultete. Ljubljana.

Jones A. 2002. Archaeological Theory and Scientific Practice. Cambridge University Press. Cambridge.

Korošec J. 1964. Kulturne ostaline na kolišču ob Resnikovem prekopu odkrite v letu 1962. Poročilo o raziskovanju neolita in eneolita v Sloveniji I: 25-46.

Korošec P., Korošec J. 1969. Najdbe s koliščarskih naselbin pri Igu na Ljubljanskem barju. Catalogi Archaeologici Sloveniae 3. Narodni muzej. Ljubljana. 
LaMotta V. M., Schiffer B. 1997. Formation processes of house floor assemblages. In P. M. Allison (ed.), The Archaeology of Household Activities. Routledge, New York: 19-29.

Mlekuž D., Budja M. and Ogrinc N. 2006. Complex settlement and the landscape dynamic of the Iščica floodplain (Ljubljana Marshes, Slovenia). In M. Budja (ed.), 13th Neolithic Seminar. Documenta Praehistorica 33: 253-271.

Osterc V. 1975. Mineralna sestava in mikrostruktura keramike s kolišča ob Maharskem prekopu I. Poročila o raziskovanju neolita in eneolita v Sloveniji IV: 123-134.

Rice P. M. 1987. Pottery Analysis. A Sourcebook. The University of Chicago Press. Chicago and London.

Schiffer B. 1987. Formation processes of the archaeological record. University of Utah Press. Salt Lake City.

Skibo J. M. 1992. Understanding Pottery Function. Ma nuals in Archaeological Method, Theory and Technique. Springer. New York.

Smith M. 1988. Function from Whole Vessel Shape: A Method and an Application to Anasazi Black Mesa, Arizona. American Anthropologist, New Series 90(4): 912-923.

Stritar A. 1975. Pedološke raziskave kolišča ob Maharskem prekopu pri Igu - 1973. leta. Poročilo o raziskovanju raziskovanju paleolita, neolita in eneolita $v$ Sloveniji 4: 142-144.

Stritar A., Lobnik F. 1985. Pedološke raziskave kolišča Parte pri Igu. Poročilo o raziskovanju paleolita, neolita in eneolita $v$ Sloveniji 13: 67-73.

Šercelj A. 1973. Poročilo o ksilotonskih raziskavah kolišča ob Maharskem prekopu - raziskovanja leta 1972. Poročilo o raziskovanju neolita in eneolita $v$ Sloveniji 3: 69-70.
1975. Analize makroskopskih in mikroskopskih rastlinskih ostankov s kolišča ob Maharskem prekopu, izkopavanja 1973. in 1974. leta. Poročilo o raziskovanju paleolita, neolita in eneolita v Sloveniji 4: 115122.

1981-1982. Pomen botaničnih raziskav na koliščih Ljubljanskega barja. Poročilo o raziskovanju paleolita, neolita in eneolita v Sloveniji 9-10: 101-106.

Šercelj A., Culiberg M. 1978. Ksilotomske analize lesa iz kolišča ob Maharskem prekopu - izkopavanja 1976 in 1977. Poročilo o raziskovanju paleolitika, neolitika in eneolitika v Sloveniji 6: 103-107.

Terry R., Chilingar G. 1955. Summary of 'Concerning some additional aids in studying sedimentary formations' by M. S. Shvetsov. Journal of Sedimentary Research 25: 229234.

Tite M. S. 2008. Ceramic production, provenance and use - a review. Archaeometry 50(2): 216-231.

Turk J. 2006. Ugotavljanje paleoekoloških sprememb na Ljubljanskem Barju v holocenu na primeru sedimentov z Resnikovega prekopa. In A. Velušček (ed.), Resnikov prekop. Najstareǰ̌a koliščarska naselbina na Ljubljanskem Barju. Operi Instrituti Archaeologici Sloveniae 10. Institute of Archaeology at ZRC SAZU, Ljubljana: 93-98.

Velušček A. (ed.) 2006. Resnikov prekop. The oldest piledwelling settlement in the Ljubljansko barje. Opera Instituti Archaeologici Sloveniae 10. Institute of Archaeology at ZRC SAZU. ZRC Publishing. Ljubljana.

Whitbread I. K. 1995. Greek Transport Amphorae. A Petrological and Archaeological Study. Fitch Laboratory Occasional Paper 4. The British School at Athens. The Short Run Press. Exeter. 